angle of $104^{\circ}$, while the telescope's magnifying power is $15^{\circ}$. The definition of the prisms had been previously tested on bright hydrogen lines in a dark field, and found to be admirably perfect, much to the credit of their maker, Mr. Adam Hilger.

Take it all' in all, nothing less powerful should be employed in critical researches; and as these prisms give together a dispersion of $24^{\circ}$ between $\mathrm{A}$ and $\mathrm{H}$, the pictures they offer, with the further assistance of the telescope, have a physiognomy comparable at once with either Angstrom's or Kirchhoff's standard solar spectrum maps, so universally respected over the whole world.

$$
\text { C. Piazzi Smyth }
$$

Astronomer Royal for Scotland

\section{ELECTRIC NAVIGATION}

$\mathrm{T}^{\mathrm{H}}$ idea of propelling a boat through water by the motive power of electricity is no new one. The invention of the electromagnet showed the power of an electric current to produce a mechanical force. It was no very difficult matter, therefore, for the electricians of fifty years ago to utilise the force of the electromagnet to drive small electromagnetic engines; and from the small beginnings of Dal Negro, Henry, Ritchie, and Page, grew up a group of electric motors which only awaited a cheap production of electric currents to become valuable laboursaving appliances. Nor was it a very long stride to foresee that if a sufficiently powerful battery could be accommodated on board a boat, it might be possible to propel a vessel with electromagnetic engines drawing their supply of currents from the batteries. This suggestion- one of the earliest, indeed, of the many applications of the electromagnet-was made by Prof, Jacobi of St. Petersburg, who, in 1838 , constructed an electric boat. Fig. 1, which we here reproduce from Hessler's "Lehrbuch der Technischen Physik," represents the rude electro-magnetic motor or engine, which Jacobi devised for the driving of his boat. Two series of electro-magnets of horse-shoe form were fixed upon substantial wooden frames, and between them, centred upon a shaft which was connected to the paddle-wheels, rotated a third frame, carrying a set of straight electro-magnets. By means of a commutator made of notched copper wheels, which changed the direction of the current at appropriate intervals, the moving electro-magnets were first attracted towards the opposing poles, and then, as they neared them, were caused to be repelled past, so providing a means of keeping up a continuous rotation. This

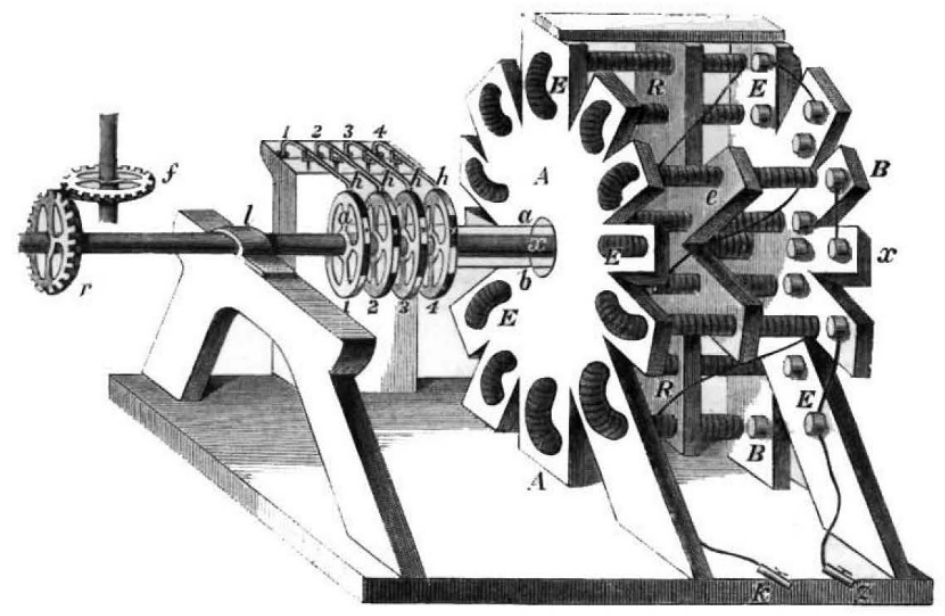

FIG. I.-The Engine of Jacobi's Electric Boat, $188_{3} 8$.

machine was worked at first by a Daniell's battery of 320 couples, containing plates of zinc and copper, 36 square inches each, and excited by a charge of sulphuric acid and sulphate of copper. The speed attained with this battery did not reach so much as $1 \frac{1}{4}$ miles per hour. But in the following year, 1839, the improvement was made of substituting 64 Grove's cells, in each of which the platinum plates were 36 square inches in area. The boat, which was about 28 feet long, $7 \frac{1}{2}$ broad, and not quite 3 feet in depth, was propelled, with a convoy of fourteen persons, along the River Neva, at a speed of $2 \frac{1}{4}$ (English) miles per hour.

A second attempt at electric navigation was made on a much smaller scale about two years ago by M. G. Trouvé, the well-known manufacturer of electric apparatus, of Paris, who constructed an electric skiff, in which he placed one of his small and compact motors, and drove it by means of a battery of Planté's accumulators, previously charged.

The Neva and the Seine having been respectively the scenes of the first and second efforts at electric navigation, it was fitting that the Thames should be the scene of the third, and most recent one.

The electric launch Electricity, which made its trial trip on Thursday, September 28, I882, on the water s of the Thames, is certainly a great advance upon that which had been previously attained. This boat, the arrangements of which have been designed and carried out by Mr. A. Reckenzaun, C.E., mechanical engineer to the Electrical Power Storage Company of Millwall, is of iron, and is a trifle less in length than the wooden boat which Jacobi propelled. She will carry twelve persons, though at the trial trip but four were on board. The screwpropeller is calculated to run at 350 revolutions per minute, the two Siemens' motors running at 950 revolutions. The accumulators, which weigh $I \frac{1}{4}$ tons, are calculated to supply the necessary current for seven or eight hours of continuous work.

Having been one of a privileged party of four, the first ever propelled upon the waters of the river Thames by the motive power of electricity, I think some details of this latest departure in the applications of electric science may be of interest. At half-past 3 on the afternoon of Sept. 28 I found myself on board the little vessel Electricity, lying at her moorings off the wharf of the works of the Electrical Power Storage Company at Millwall. Save for the absence of steam and steam machinery, the little craft would have been appropriately called a steam launch. 
She is 25 feet in length, and about 5 feet in the beam, drawing about 2 feet of water, and fitted with a 22 -inch propeller screw. On board were stowed away under the flooring and seats, fore and aft, 45 mysterious boxes, each

a cube of absut 10 inches in cimensions. These bo::es were nothirg else than electric accumulators of the latest type as devised bv Messrs. Sellon and Volckmar, being a modification of the well-kn swn Plsnté accumulator. Fully
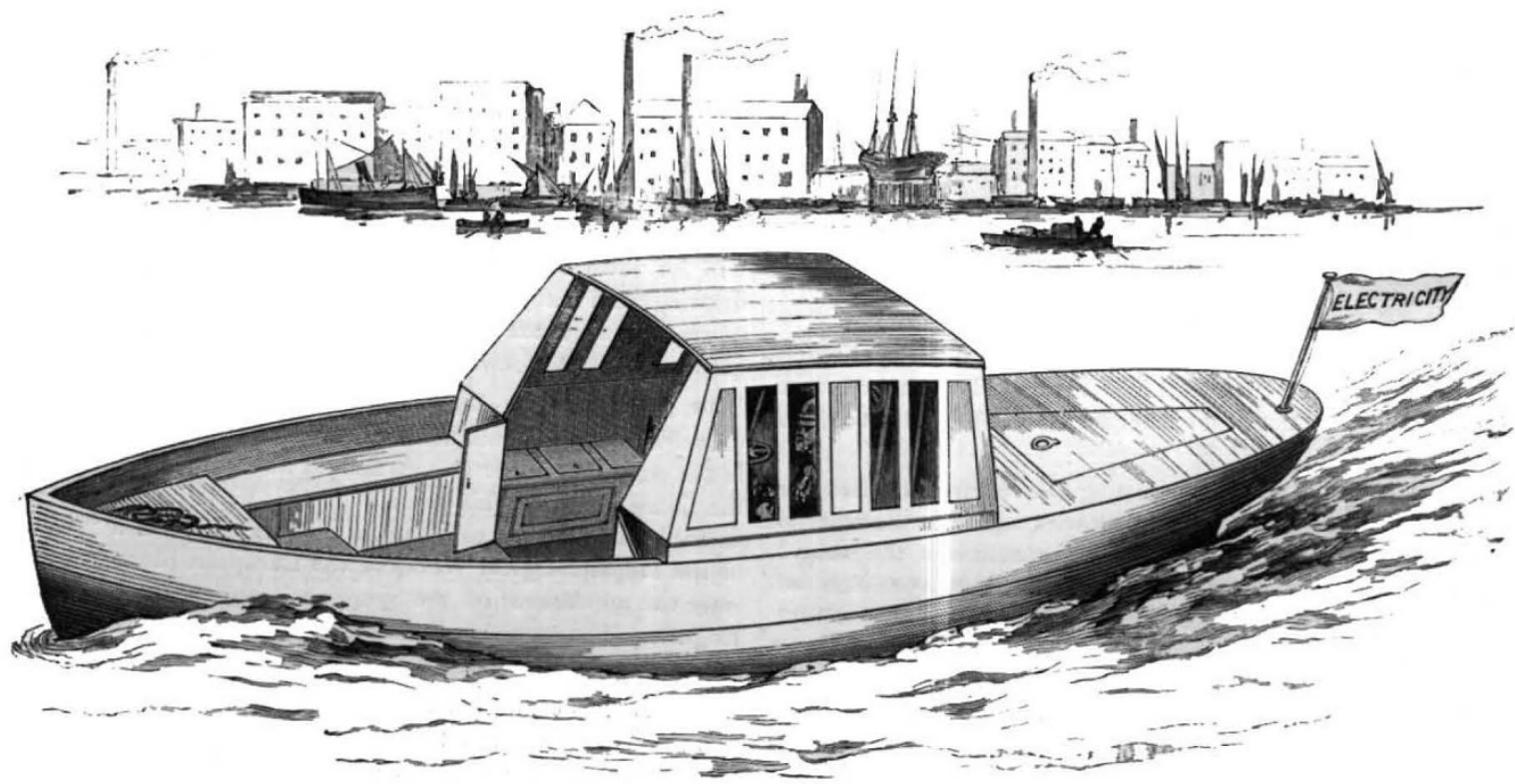

Fra, 2.-The Electric Launch.

charged with electricity by wires leading from the dynamos or generators in the works, they were calculated to supply power for six hours at the rate of four horsepower. These storage cells were placed in electrical connection with two Siemens' dynamos of the size known as D 3, furnished with proper reversing-gear and regulators, to serve as engines to drive the screw propeller. Either or both of these motors could be "switched "into circuit at will. In charge of the electric engines was Mr. Gustave Phillipart, jun., who has been associated with Mr. Volckmar in the fitting up of the electric launch. Mr. Volckmar himself and an engineer completed, with the writer, the quartette who made the trial trip. After a few minutes' run down the river and a trial of the powers of the boat, to go forward, slacken, or go astern at will, her head was turned Citywards, and we sped-I cannot say steamedsilently along the southern shore, running about eight knots an hour against the tide. At 4.37 London Bridge was reached, where the head of the launch was put about, while a long line of onlookers from the parapets surveyed the strange craft that without steam or visible powerwithout even a visible steersman-made its way against wind and tide. Slipping down the ebb the wharf at Millwall was gained at 5.1 , thus in 24 minutes terminating the trial trip of the Electricity. For the benefit of electricians I may add that the total electromotive force of the accumulators was 96 volts, and that during the whole of the long run the current through each machine was steadily maintained at 24 amperes. Calculations show that this corresponds to an expenditure of electric energy at the rate of 3 I'II horse-power.

Fig. 2 gives a general view of the electric launch afloat. The arrangements of the driving machinery are shown in Fig. 3, which is a section of the boat, taken amidships. The accumulators, B B, are stowed as low as possible, and form an admirable ballast. The two Siemens' dynamos are connected by belts with an overhead countershaft, and arranged with a friction-clutch, by means of which one dynamo can be thrown in or out of gear at will. From the countershaft a third belt passes down to a pulley on the axis of the screw. Each of the engines is provided with two pairs of brushes at the commutators,

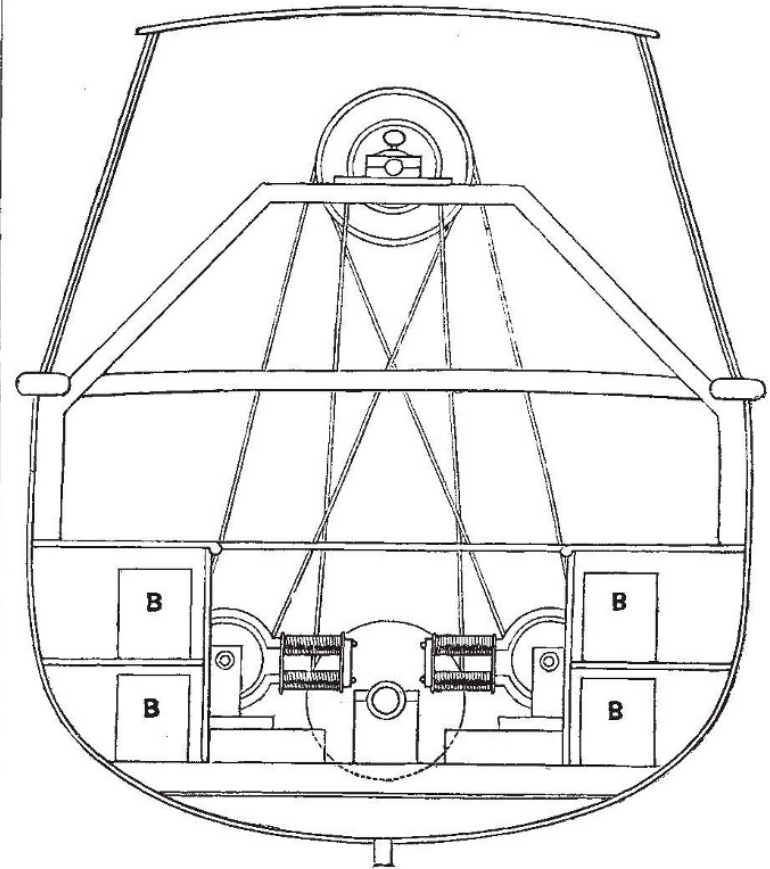

FiG. 3.-Section of electric launch showing driving machinery.

one pair having a lead forward, the other backward, enabling the motion to be reversed by raising or lowering one or other pair of brushes. C $f$ the practical success 
of this little craft there can be no question. Of its economy it is premature to speak. It is, however, greatly in favour of electric navigation, that such machinery may be both lighter and more compact than that of steamengines of corresponding power; that the noise and vibration is very greatly reduced; and that, lastly, there is a complete absence of the nuisance of smoke, which appears to be inseparable from steam navigation.

\section{SilvanUs P. THOMPSON}

\section{NOTES}

AT the sitting of October 2 of the Academy of Sciences, M. Dumas delivered an address on his friend, Prof. Wœhler, of Göttingen, one of the eight Foreign Associates of the French Academy, whose death had been announced by telegram. $\mathrm{He}$ also gave the list of the eight missions sent by the French Government to observe the transit of Venus. The total expense charged against the national exchequer is estimated at $1,200,000$ francs.

Prof. MOSELEY, who is conducting the researches which the Cardiff Naturalists' Society is making with regard to the fisheries in the sea beyond Lundy Island and the mouth of the Bristol Channel, has been successful in obtaining a specimen of "Arnoglossus Lophotes," a Pleuronectid with the anterior rays of the dorsal fin curiously elongated, hitherto known only from two dried skins in the Couch collection, the locality of which was uncertain. This specimen, which is now in the British Museum, establishes the validity of Dr. Günther's classification of this fish as a distinct British species.

AN excavation for geological purposes was made in the New Forest during the last fortnight of September by Mr. J. W. Elwes of Otterbourn, and Mr. T. W. Shore of Southampton, who obtained special permission for this purpose. A considerable area of the Brockenhurst bed was exposed by the removal of about twelve feet of overlying strata near the railway cutting which yielded such interesting specimens forty years ago. More than a thousand good specimens were obtained on the present occasion, comprising seventy species of molluscs and some corals. The work was directed by Mr. Keeping, of the Woodwardian Museum, Cambridge.

AMONG the special features of the Munich Electrical Exhibition is a telephone transmitting thither pieces of music performed at Oberammergau, which is about 63 miles distant; also a giant telephone, which transmits concert pieces performed in the English Café, so as to be audible to the whole of an audience in a large hall at the Palace. A special interest also attaches to the transmission of power by a single wire from the coal-mines of Miesbach, about 37 miles distant, as the possibility of utilising the heat of coal at a distance without transport of the coal is concerned.

IT has been ascertained that the first experiment with air balloons was made by Montgolfier the elder, at Avignon, when he was a resident in this city in the month of November, 1782. He sent up in his room a parallelopiped of canvas, of which the measurement was 40 cubic feet, and which had been heated by burning paper inside. The room is still in existence, in a house in front of which the Municipality have placed a commemorative inscription. The window fronting the street is adorned with an iron balcony, at both ends of which a small gilt balloon has been placed. The anniversary will be celebrated in Paris by a banquet given by the Academy of Aërostation, and very probably a local celebration will take place in Avignon.

ACTIVE preparations are being made for an electrical and gas exhibition, to be opened at the Crystal Palace on October 24 .

A wORK on South African Butterflies- "A Monograph of the Extra-Tropical Species," by Mr. Roland Trimen-is announced by Messrs. Trübner. It will be much more than a new edition of the author's former work; the plates will be entirely new.

WE are asked to state that an article by Dr. James Croll, F.R.S., entitled " Evolution by Force Impossible; a New Argument for Theism," written before his recent illness, will shortly appear in one of the quarterlies.

UNDER the title of "Boats of all Nations, drawn from Nature," Mr. G. H. Andrews proposes to publish a work in large folio, illustrative and descriptive of the origin, history, and peculiar characteristics of the smaller craft of Great Britain, Norway, Denmark, Hanover, Holland, Belgium, Spain, Italy, Greece, Turkey, Asia Minor, and North America. The work will be illustrated by thirty facsimile copies of the original drawings and many sketches of details. The interest and utility of such a work are evident, and to judge from the specimen before us Mr. Andrews is likely to do the subject justice.

In the Revista da Sociedade de Instrucçao do Porto, Prof. Oliveira regularly continues bis Catalogue of Portuguese Insects; in the current number it is carried to the end of Bembidium in the Coleoptera. In this same number is what appears to be a valuable contribution to botanical bibliography, viz. a " Review of the Hepaticological Works of the European Flora published since the appearance of the Synopsis Hepaticarum," printed in English. The author is P. Stephani, who dates from Leipzig.

IN Natural History Notes, a series of articles on "Plant Symbolism, as connected with the Early History of Mankind," by S. Marshall, F.R.Hist.S., is being published.

WE have received from the Bristol Museum and Library the Syllabus of the usual course of lectures on scientific and literary subjects, to be delivered in the Lecture Theatre, on Tuesday evenings during the winter. It is as well arranged as in previous years.

IN reference to our correspondence on the aurora we may say that Mr. E. J. Stone, director of the Radcliffe Observatory at Oxford, telegraphed to the Times on Monday night:- "An aurora has been visible this evening, extending over a large portion of the sky. It appeared in bright patches towards the south, which were continually changing. The spectrum was linear."

AT her country house in Sussex, Lady Dorothy Nevill, so well known for her active interest in natural history, has two pairs of choughs which are allowed full liberty. They fly about the grounds, but are quite tame, and come to a window or into a room to be fed. One pair has taken to a small tower on the roof of the house as a roosting place, and prevents the other pair, which has to roost in a shed, from approaching it. This year the pair built a nest on the top of the wall of the tower in a corner under the roof and laid eggs, but unfortunately failed to hatch them. Although the chough is familiarly known as a bird readily tamed, it has apparently not been observed to nest in the domestic condition before. It is hoped the birds may rear a brood next year in the tower. The nest they made is an ex. tremely neat one, deep and secure, and lined with hair and wool. It is curious that the one pair should drive the other away from the tower, where there is plenty of room for several nests. The pairs keep apart all day, and seem to lose, when thus domesticated, their natural gregarious instincts.

SHOCKS of earthquake occurred at St. Louis and parts of Illinois and Indiana on September 27.

ADVICES from Montevideo announce the arrival there of the French Venus Transit expedition. Part will observe the transit at Carmen de Patagones, and another party will go to Santa Cruz. The Brazilian astronomers will observe the transit of Venus from four stations, viz. one at Rio Janeiro, one at Pernambuco, one in the West Indies, and one about Cape Horn. 